
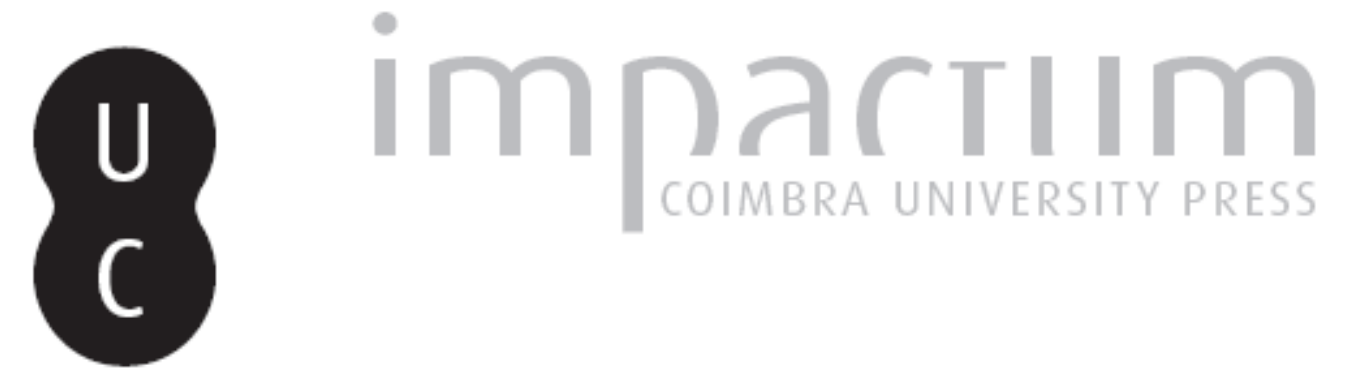

\title{
Princípio da legalidade penal como direito humano fundamental
}

\author{
Autor(es): $\quad$ Castro, Henrique Hoffmann Monteiro de
}

Publicado por: Universidade Católica de Petrópolis

URL persistente:

URI:http://hdl.handle.net/10316.2/33745

DOI:

DOI:http://dx.doi.org/10.14195/2175-0947_4-2_5

Accessed : $\quad$ 26-Apr-2023 08:48:38

A navegação consulta e descarregamento dos títulos inseridos nas Bibliotecas Digitais UC Digitalis, UC Pombalina e UC Impactum, pressupõem a aceitação plena e sem reservas dos Termos e Condições de Uso destas Bibliotecas Digitais, disponíveis em https://digitalis.uc.pt/pt-pt/termos.

Conforme exposto nos referidos Termos e Condições de Uso, o descarregamento de títulos de acesso restrito requer uma licença válida de autorização devendo o utilizador aceder ao(s) documento(s) a partir de um endereço de IP da instituição detentora da supramencionada licença.

Ao utilizador é apenas permitido o descarregamento para uso pessoal, pelo que o emprego do(s) título(s) descarregado(s) para outro fim, designadamente comercial, carece de autorização do respetivo autor ou editor da obra.

Na medida em que todas as obras da UC Digitalis se encontram protegidas pelo Código do Direito de Autor e Direitos Conexos e demais legislação aplicável, toda a cópia, parcial ou total, deste documento, nos casos em que é legalmente admitida, deverá conter ou fazer-se acompanhar por este aviso.

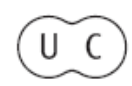



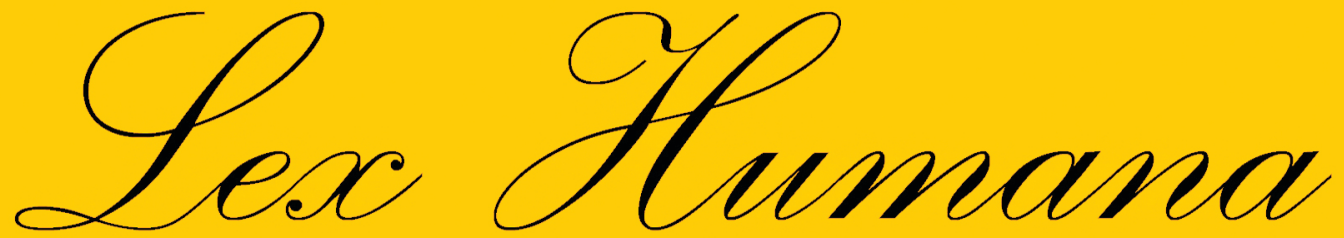

Revista do Programa de Pós-Graduação em Direito da UCP

ISSN(e) 2175-0947

Universidade Católica de Petrópolis Rua Benjamin Constant, 213 - Petrópolis - Centro CEP 25610-130

Tel: (24) 2244-4000 E-mail: lexhumana@ucp.br 


\section{Princtio do legaididade Penal como Direito Humano Fundamental}

\section{Principle of Criminal legality as a Fundamental HUMAN RIGHT"}

\section{HENRIQUE HOFFMANN MONTEIRO DE CASTRO** \\ UNIVERSIDADE GAMA FILHO, BRASIL}

Resumo: $O$ presente trabalho tem como desiderato debater o princípio da legalidade no âmbito do Direito Penal, postulado que se qualifica como direito humano fundamental. Isso porque a legalidade penal reveste-se de caráter garantidor do cidadão, possuindo caráter basilar em qualquer Estado que se pretenda Democrático de Direito, traduzindo ponto nevrálgico dos ordenamentos jurídicos que se fundem na justiça e na racionalidade. Como é indubitável que o princípio da legalidade afigura-se como garantia individual de cunho constitucional, sua análise é imprescindível para a compreensão do Direito Penal em uma visão principiológica. Para tanto, perquire-se sobre o caráter principiológico da legalidade, realiza-se reflexão sobre a íntima relação entre legalidade e Estado Democrático de Direito, perscruta-se acerca da origem histórica e do conteúdo da cláusula de legalidade, raciocina-se sobre os desdobramentos do referido postulado, são formuladas ideias sobre os mandados de criminalização, desenvolvem-se argumentos em torno de polêmicas questões que envolvem a legalidade penal e, finalmente, alguns arremates acerca do tema são realizados.

Palavras-chave: Estado Democrático de Direito; Princípio da Legalidade; Direitos Humanos.

Abstract: This work aims to discuss the principle of legality in criminal law, principle qualified as a fundamental human right. The criminal legality is a natural guarantee of citizens, having

\footnotetext{
* $\quad$ Artigo recebido em 18/03/2012 e aprovado para publicação pelo Conselho Editorial em 18/10/2012.

** Especialização em andamento pela Universidade Gama Filho, Brasil. Professor do Centro de Estudos e Aperfeiçoamento Funcional do Ministério Público de Minas Gerais, Brasil. Delegado da Polícia Civil do Mato Grosso. Professor da UNED - Faculdade de Ciências Sociais Aplicadas. Especialista em Segurança Pública pelas Faculdades Barddal. Bacharel em Direito pela Universidade Federal de Minas Gerais, Brasil. Currículo Lattes: http://lattes.cnpq.br/1172048837222922. E-mail: henriquehmc@gmail.com.
} 
basic character in any state that pretends itself democratic, reflecting main feature of the legal systems based on justice and rationality. As it is clear that the principle of legality seems to be a constitutional guarantee of individual, its analysis is essential for understanding a principled view of the criminal law. To do so, it perquires about the character of legality, reflects on the intimate relationship between legality and democratic state, peers up about the historical origin and content of the clause of legality, reasons about the consequences of this postulate, formulates ideas about the criminalization warrants, develops arguments about controversial issues involving the legality of criminal and, finally, some finishing touches are made on the subject.

Keywords: Democratic State of Law; Principle of Legality; Human Rights.

\section{Linhas Introdutórias}

O princípio da legalidade, cabe esclarecer logo de início, não é exclusivo de qualquer ramo do Direito, estando inserido no acumulado de princípios norteadores de toda a ciência jurídica. Não por outro motivo o artigo $5^{\circ}$, inciso II da Carta Magna estabelece, sem distinção de aplicação nesse ou naquele ramo jurídico, que ninguém será obrigado a fazer ou deixar de fazer alguma coisa senão em virtude de lei.

Tal garantia fundamental nasceu com o Estado de Direito, como contraponto a todas as formas de autoritarismo e abuso.

Nesse panorama, este trabalho tem como alvo debater o princípio da legalidade no âmbito do Direito Penal, postulado que se qualifica como direito humano fundamental. Isso porque a legalidade penal reveste-se de caráter garantidor do cidadão ante a atuação penal estatal desenfreada, impedindo uma persecução penal norteada por interesses egoísticos das autoridades.

Como é indubitável que o princípio da legalidade afigura-se como garantia individual de cunho constitucional, sua análise é imprescindível para a compreensão do Direito Penal em uma visão principiológica.

Nesse cenário, pretender-se-á nesse artigo (a) perquirir sobre o caráter principiológico da legalidade, (b) refletir sobre a íntima relação entre legalidade e Estado Democrático de Direito, (c) perscrutar acerca da origem histórica e do conteúdo da cláusula de legalidade, (d) raciocinar sobre os desdobramentos do referido postulado, (e) formular 
ideias sobre os mandados de criminalização, (f) desenvolver argumentos em torno de polêmicas questões que envolvem a legalidade penal e, por final, $(\mathrm{g})$ realizar alguns arremates acerca do tema.

\section{Postulado da legalidade enquanto norma-princípio}

Hodiernamente, a doutrina e a jurisprudência praticamente não divergem no reconhecimento da juridicidade dos princípios. Reconhecem-nos enquanto espécies do gênero norma, juntamente com as regras, possuindo especial valor para o arcabouço jurídico pátrio.

Essa relevante distinção entre princípios e regras pode ser sintetizada da seguinte forma ${ }^{123}$ : a) princípio possui pressuposto fático heterogêneo, enquanto regra tem pressuposto fático homogêneo; b) princípio sofre antinomia jurídica imprópria (colisão de princípios solucionada por critério de ponderação), ao passo que regra sofre antinomia jurídica própria (conflito de regras solucionado pelos critérios de hierarquia, especialidade e cronologia); c) princípio tem dimensão da importância (peso ou valor), enquanto regra tem dimensão de validade; d) princípio traduz mandamento de otimização (norma deve ser cumprida na maior medida possível), ao passo que regra consiste em mandamento de definição (norma deve ser cumprida na medida exata).

Nessa linha de ideias, fácil constatar que a legalidade deve ser considerada como princípio, e não como regra, porquanto encerra a noção de mandado de otimização, que possui pressuposto fático heterogêneo, tendo a dimensão da importância, afirmação que será confirmada a seguir.

\section{3. Íntima relação entre legalidade e Estado Democrático de Direito}

Feita essa importante diferenciação, cabe grifar que o princípio da legalidade está intimamente relacionado com o Estado de Democrático Direito, tendo em vista que qualquer Estado Moderno preza pela ideia básica do domínio da lei. ${ }^{4}$

\footnotetext{
${ }^{1}$ DWORKIN, Ronald. Levando os direitos a sério. 2. ed. São Paulo: Martins Fontes, 2007, p. 39.

${ }^{2}$ BARCELLOS, Ana Paula de. A eficácia jurídica dos princípios constitucionais: o princípio da dignidade da pessoa humana. 2. ed. Rio de Janeiro: Renovar, 2008.

${ }^{3}$ ALEXY, Robert. Constitucionalismo discursivo. Porto Alegre: Livraria do Advogado, 2008, p. 64.

${ }^{4}$ BRANCO, Paulo Gustavo Gonet; COELHO, Inocêncio Mártires; MENDES, Gilmar Ferreira. Curso de direito constitucional. 2. ed. São Paulo: Saraiva, 2008, p. 41-42.
} 
Esse postulado possui importância tal para o sistema jurídico pátrio que é considerado a base do Estado Moderno, além de alicerce de um Direito Penal que aspira à segurança jurídica.

Nessa esteira, a legalidade preserva a liberdade e a dignidade do homem, e impede o uso arbitrário do poder pelo Estado, protegendo-o em face do abuso do exercício da persecução penal. A legalidade penal obsta que a pena seja utilizada de forma contingente, limitando sobremaneira a discricionariedade das autoridades estatais.

A Constituição Federal o posiciona como vértice do sistema jurídico pátrio, de modo que sua existência se coloca como garantia para a liberdade e segurança da coletividade. Esse postulado consubstancia-se em peça mestra do sistema penal.

O postulado da legalidade, não é exagero afirmar, repercute a concepção de patrimônio comum da legislação penal dos povos civilizados. ${ }^{5}$ Trata-se da pedra angular ${ }^{6}$ do Direito Penal, por conferir ao indivíduo a possibilidade de prever a intervenção do poder punitivo do Estado ${ }^{7}$

Possui vocação eminentemente garantista, estando umbilicalmente ligada aos Estados democráticos. Tanto que, historicamente, uma das primeiras providências de todo Estado Ditatorial é justamente revogar essa norma, sendo exemplo marcante o Código Penal da Alemanha de 1935 (que punia atos contrários aos “sentimentos do povo alemão").

Sua importância é tamanha que a sua supressão acarreta o aniquilamento da proteção mais fundamental conferida à pessoa, colocando o indivíduo numa incômoda iminência de ser alvo da reação penal do Estado por fatos mais comezinhos, segundo um juízo provisório realizado pelas autoridades públicas.

\section{Origem histórica e conteúdo da cláusula de legalidade}

Não há consenso acerca da origem histórica do princípio da legalidade.

Afirma parcela da doutrina que o princípio da legalidade teve sua gênese na Magna Carta de 1215, porquanto esse documento tinha como norte essencial a proteção dos súditos em face das intromissões arbitrárias do Estado. ${ }^{8}$ Nesse sentido é que estabelece o art. 39 do

\footnotetext{
${ }^{5}$ LUISI, Luiz. Princípios constitucionais penais. 2. ed. Porto Alegre: Sergio Antônio Fabris Editor, 2003. p. 21. ${ }^{6}$ PRADO, Luiz Regis. Curso de Direito Penal brasileiro: parte geral. 5. ed. São Paulo: Revista dos Tribunais, 2005, p. 140.

${ }^{7}$ BATISTA, Nilo. Introdução crítica ao direito penal brasileiro. Rio de Janeiro: Revan, 2001, p. 67.

${ }^{8}$ GRECO, Rogério. Curso de Direito Penal: parte geral. 5. ed. Niterói: Impetus, 2005, p. 104.
} 
referido diploma que nenhum homem livre será detido, preso, despojado de sua propriedade ou de sua liberdade senão em virtude de um juízo legal de seus pares e segundo as leis do país.

Outros aduzem que suas raízes históricas remontam ao Bill of Rights e à Declaração dos Direitos do Homem e do Cidadão.?

Já para uma terceira corrente doutrinária, o postulado da legalidade se originou, na verdade, do Direito Medieval, especificamente das instituições do Direito Ibérico. ${ }^{10}$

Posteriormente à positivação desse princípio, a legalidade foi aperfeiçoada por Feuerbach, com base em sua teoria da coação psicológica, segundo a qual a noção de possibilidade jurídica da pena só se sustenta se a ameaça de um mal se der por meio de lei. ${ }^{11}$ Foi esse estudioso que consagrou a expressão nullum crimen, nulla poena sine praevia lege. ${ }^{12}$

A protuberância desse postulado sempre foi reconhecida pelo ordenamento jurídico pátrio, tanto que foi consagrado em todas as Constituições e em todos os Códigos Penais do Brasil, sem exceção. No que tange ao âmbito constitucional, restou consignado nas Constituições de 1824 (art. 179, \2), de 1891 (art. 72, \15), de 1934 (art.113, \26), de 1937 (art. 122), de 1946 (art. 141, \27), de 1967 (art.153, \16) e de 1988 (art. 5, XXXIX e XL). Quanto à seara infraconstitucional, ficou estabelecido no Código Penal de 1831 (arts. $1^{\circ}$ e 33), de $1890\left(\right.$ art. $\left.1^{\circ}\right)$ e de $1940\left(\operatorname{art} .1^{\circ}\right)$.

Dessa forma, o princípio da legalidade é expressamente consagrado tanto em nível constitucional quanto na esfera infraconstitucional. Encontra-se insculpido no art. $1^{\circ}$ do Código Penal, no art. $5^{\circ}$, XXXIX da Constituição (cláusula pétrea - art. 60 , $\$ 4^{\circ}$ da CF).

Esse preceito exerce a nobre função de assegurar o prévio conhecimento das infrações penais e das sanções a elas cominadas, garantindo que alguém somente terá a liberdade suprimida nos estritos termos da lei penal. ${ }^{13}$

Por meio dessa garantia, a criação de leis penais é matéria atribuída ao Poder Legislativo, especificamente o Poder Legiferante da União (art. 22, I, da CF).

Cuida-se de princípio cuja função se mostra nitidamente garantidora (de garantia da lei penal). ${ }^{14} \mathrm{O}$ postulado possui papel de regulamentação da amplitude e intensidade do

\footnotetext{
${ }^{9}$ TOLEDO, Francisco de Assis. Princípios básicos do Direito Penal. 5. ed. São Paulo: Saraiva, 2002, p. 21.

${ }^{10}$ MARQUES, José Frederico. Tratado de Direito Penal. v. 1. Campinas: Bookseller, 1997, p. 181.

${ }^{11}$ FRAGOSO, Heleno Cláudio. Lições de Direito Penal: parte geral. Rio de Janeiro: Forense, 1993, p. 92.

${ }^{12}$ FEUERBACH, Paul Johann Anselm Ritter Von. Tratado de Derecho Penal. Buenos Aires: Hamurabi, 1989, p. 63.

13 _. Introdução crítica ao direito penal brasileiro. Rio de Janeiro: Revan, 2001, p. 65.

14 . Princípios básicos do Direito Penal. 5. ed. São Paulo: Saraiva, 2002, p. 22.
} 
exercício do direito de punir do Estado. ${ }^{15}$ Consiste em verdadeira cláusula de liberdade, na medida em que sua missão fundamental é proteger o status libertatis dos cidadãos em face de um poder punitivo estatal desarrazoado. ${ }^{16}$ Assegura a preponderância do direito positivo como mecanismo regulador dos conflitos sociais. ${ }^{17}$

Noutro giro, a legalidade penal está intimamente relacionada com o requisito do tipo penal - e consequentemente do crime - denominado tipicidade, que significa a adequação do fato concreto ao modelo previsto na norma penal. Destarte, a tipicidade traduz a elaboração científica do princípio da legalidade no contexto do Direito Penal. ${ }^{18}$

Esse princípio possui dois significados: a) político, consistente na garantia constitucional dos direitos humanos (proteção do ser humanos); b) jurídico, pelo qual ninguém é obrigado a fazer alguma coisa senão em virtude de lei. ${ }^{19}$ Encaixa-se, a toda evidência, nos direitos fundamentais de primeira dimensão.

Ademais, não se pode atribuir um único fundamento para a cláusula de legalidade. Podem ser citados como seus fundamentos: a) princípio da culpabilidade, o qual pressupõe o prévio conhecimento da lei penal; b) princípio da separação dos Poderes, pois só o Parlamento pode limitar a liberdade do cidadão; c) proteção da confiança do cidadão, que pretende agir conforme a lei; d) garantia de objetividade da lei penal, por estabelecer o que constitui o crime prévia e objetivamente. ${ }^{20}$

Enquanto a Parte Geral do Código Penal prevê de forma geral o princípio da legalidade, a Parte Especial concretiza esse postulado, através dos tipos penais. Com efeito, a Parte Especial do Diploma Penal se converte na Magna Carta do delinquente. ${ }^{21}$

Além disso, para que uma lei seja válida e produza os efeitos ambicionados pelo legislador, deve não apenas seguir os trâmites legais para a sua criação, senão estar em consonância com a Constituição no que tange à defesa dos bens jurídicos contra ataques relevantes. Não por outro motivo é que a legalidade se divide em (a) legalidade formal e (b)

\footnotetext{
${ }^{15}$ MORAES, Alexandre de. Direitos Humanos fundamentais: teoria geral. 4. ed. São Paulo: Atlas, 2002, p. 221.

${ }^{16}$ CAPEZ, Fernando. Curso de Direito Penal: parte geral. 8. ed. São Paulo: Saraiva, 2005, p. 40.

${ }^{17}$ HASSEMER, Winfried. Fundamentos del Derecho Penal. Barcelona: Bosch, 1984, p. 311-312.

${ }^{18} \mathrm{NUCCl}$, Guilherme de Souza. Código Penal comentado. 10. ed. São Paulo: Revista dos Tribunais, 2010, p. 53.

19 C. Código Penal comentado. 10. ed. São Paulo: Revista dos Tribunais, 2010, p. 52.

20 ESTEFAM, André. Direito Penal. v. 1. São Paulo: Saraiva, 2010, p. 116.

21 _. Princípios básicos de Direito Penal. 5. ed. São Paulo: Saraiva, 2002, p. 25.
} 
legalidade material. ${ }^{22}$ Legalidade formal, então, espelha a ideia de seguir o procedimento formal para a criação da lei. Legalidade material, a seu turno, assume o significado do ajustamento do conteúdo da lei aos direitos e às garantias fundamentais. ${ }^{23}$

\section{Desdobramentos do princípio da legalidade}

O postulado da legalidade traz consigo mais que a mera concepção de não haver crime sem lei anterior que o defina ou pena sem prévia cominação legal, ramificando seu sentido a outros princípios de relevância inquestionável.

A lex praevia (nullum crimen nulla poena sine lege praevia), também denominada princípio da anterioridade penal, demanda que a lei tipificadora seja anterior à conduta incriminada, exceto a norma for favorável ao acusado. Em outras palavras, a norma incriminadora que define a tipicidade da conduta deve ser anterior ao fato que pretende repreender penalmente.

O fundamento dessa garantia se ancora na chance que se dá ao cidadão de conhecer previamente o conteúdo do injusto, conferindo maior estabilidade na vida em sociedade.

Se no momento da realização da conduta sua consequência jurídica era uma, o indivíduo não pode responder posteriormente de maneira mais gravosa. Isso assegura a preservação das regras do jogo. ${ }^{24}$

Outrossim, outra vertente que esse direito possui é a de que a lei penal somente pode atingir fatos posteriores à sua vigência, isto é, os fatos supervenientes a sua entrada em vigor (novatio legis in mellius ou vedação à novatio legis in pejus). A essa segurança também se dá o nome de princípio da irretroatividade da lei penal maléfica, que combate as chamadas lex ex post facto.

O termo inicial da norma penal incriminadora é sempre a data de sua vigência. Já se a norma penal for benéfica, há duas correntes doutrinárias acerca do termo a quo: a) data da publicação, em razão do princípio da economia; b) data da entrada em vigor, em função do princípio da segurança jurídica.

A lex scripta (nullum crimen nulla poena sine lege scripta), por sua vez, exige que a criação ou o agravamento de crimes ocorra por instrumento escrito. Isso porque não há Direito vagando fora da lei ${ }^{25}$, o que impede a criação de crimes e penas pelo costume.

\footnotetext{
${ }^{22}$ CERNICCHIARO, Luiz Vicente; COSTA JUNIOR, Paulo José da. Direito Penal na Constituição. 3. ed. São Paulo: Revista dos Tribunais, 1995, p. 17.

23 _. Curso de Direito Penal: parte geral. 5. ed. Niterói: Impetus, 2005, p. 103-104.

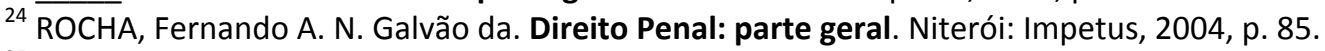

25 . Princípios básicos de Direito Penal. 5. ed. São Paulo: Saraiva, 2002, p. 24.
} 
Percebe-se que essa decorrência do princípio da legalidade é que fornece os subsídios para o estabelecimento das hipóteses de admissibilidade ou exclusão do costume no Direito Penal. O direito consuetudinário não constitui fundamento hábil a agravar a situação do criminoso, sendo admitido tão somente para integrar elementos secundários da figura penal. A única fonte de produção do Direito Penal é a lei. ${ }^{26}$

Importante destacar que a legalidade penal não impede a incidência do princípio da adequação social, segundo o qual não devem ser criminalizadas ou devem ser descriminalizadas condutas socialmente aceitas como inofensivas a bens jurídicos. No entanto, é essencial sublinhar que o princípio da adequação social não tem o condão de revogar tipos penais incriminadores, destinando-se ao legislador para que adapte o Direito Penal a uma determinada sociedade. Logo, o princípio da adequação não revoga crimes, mas sim norteia a atuação legislativa e permite que o julgador afaste a tipicidade material das infrações penais em situações excepcionais.

De outro lado, a lex certa (nullum crimen nulla poena sine lege certa), conhecida também como princípio da taxatividade ou estrita legalidade, proíbe a lei penal genérica, indeterminada ou vaga, o que significa dizer que a norma penal deve ser clara e precisa. É imprescindível que a lei defina o fato criminoso, enunciando com clareza os atributos essenciais da conduta humana de forma a torna-la inconfundível com outra. ${ }^{27}$

Nesse sentido, o tipo penal não deve deixar margens a dúvidas nem abusar do emprego de expressões genéricas ou vazias. Além disso, para que desempenhe função pedagógica, necessita ser acessível a todos, e não apenas aos juristas. ${ }^{28}$ Em outras palavras, o que se objetiva é:

evitar o arbitrium judicis através da certeza da lei, com a proibição da utilização excessiva e incorreta de elementos normativos, de casuísmos, cláusulas gerais e de conceitos indeterminados ou vagos. ${ }^{29}$

Exemplo de tipo penal aberto é aquele previsto no artigo $6^{\circ}$ do Código Penal da União Soviética de 1926, que estabelecia que "reputa-se perigosa toda ação ou omissão dirigida contra a estrutura do Estado soviético, ou que lese a ordem jurídica criada pelo regime

\footnotetext{
26 . Direito Penal: parte geral. Niterói: Impetus, 2004, p. 85.

27 LOPES, Maurício Antônio Ribeiro. Princípios penais constitucionais: o sistema das constantes constitucionais. São Paulo, RT, Fascículos Penais, Ano 89, v. 779, 2000, p. 426.

28 _. Princípios básicos do Direito Penal. 5. ed. São Paulo: Saraiva, 2002, p. 29.

29 _ Curso de Direito Penal brasileiro: parte geral. 5. ed. São Paulo: Revista dos Tribunais, 2005, p.

133.
} 
dos trabalhadores e camponeses". ${ }^{30}$ A existência desse tipo de dispositivos penais dessa estirpe permite a punição de qualquer conduta que se considere perigosa, fazendo prevalecer a forma em detrimento da matéria. ${ }^{31}$

Curial destacar, por oportuno, que essa proibição de cláusulas gerais não alcança os crimes culposos, porque neles o legislador não tem condições de pormenorizar todas as condutas humanas ensejadoras da composição típica. ${ }^{32}$ Contudo, há doutrina em sentido contrário sustentando que os crimes culposos encontram-se em dissonância com a exigência de taxatividade, tendo em conta que tais tipos abertos identificam apenas o resultado naturalístico indesejado, deixando para o julgador a tarefa de identificar a conduta violadora do dever de cuidado objetivo. ${ }^{33} 34$

A lex stricta (nullum crimen nulla poena sine lege stricta), a seu turno, não permite a analogia para criar e cominar penas. Logo, não se aceita a analogia in malan partem para alterar o preceito incriminador. A analogia consiste na aplicação dos princípios de uma norma a outro caso que não o expressamente contemplado. ${ }^{35}$

Destarte, a analogia importa aplicar, para uma situação não expressamente prevista em lei, a solução prevista para caso semelhante. Todavia, no Direito Penal, não se pode aplicar pena para fato não previsto como crime, mesmo que seja bastante semelhante a outro cuja previsão autorize a intervenção penal. ${ }^{36}$

Fácil notar que essa decorrência do postulado da legalidade é que confere a base para se definir as situações de admissibilidade ou exclusão da analogia no Direito Penal.

Grife-se que a proibição destacada não se confunde com interpretação extensiva, que é admitida no Direito Penal. Enquanto a analogia corresponde à transferência da norma para outro âmbito, a interpretação extensiva consiste na mera ampliação da norma dentro do seu próprio âmbito. ${ }^{37}$

Por fim, importante sublinhar que não se cria infração penal por meio de medida provisória (art. $62, \S 1^{\circ}, \mathrm{I}, \mathrm{b}, \mathrm{da} \mathrm{CF}$ ). Quando muito, a doutrina somente admite a edição de

\footnotetext{
${ }^{30}$ GARCIA, Basileu. Instituições de direito penal. v. 1. t. 1. 5. ed. São Paulo: Max Limonad, 1980, p. $150-151$. 31 _. Código Penal comentado. 10. ed. São Paulo: Revista dos Tribunais, 2010, p. 54.

32 - Curso de Direito Penal: parte geral. 8. ed. São Paulo: Saraiva, 2005, p. 44.

33 _ Princípios básicos do Direito Penal. 5. ed. São Paulo: Saraiva, 2002, p. 136.

34 _ Lições de Direito Penal: parte geral. Rio de Janeiro: Forense, 1993, p. 157.

${ }_{35}$ RÁO, Vicente. O direito e a vida dos direitos. v. 1. São Paulo: Revista dos Tribunais, 1991, p. 458.

36 _. Direito Penal: parte geral. Niterói: Impetus, 2004, p. 86.

37 Introdução dos fundamentos do Direito Penal. Porto Alegre: Sérgio Antônio Fabris, 2005, p. 356.
} 
medida provisória relativa a Direito Penal cujo conteúdo seja favorável ao autor do fato típico. ${ }^{38}$

\section{Mandados de criminalização}

A Constituição brasileira, a exemplo de diversas outras como as da Alemanha, Espanha, França e Itália, define mandados de criminalização, que correspondem a hipóteses em que o legislador deve necessariamente intervir para estabelecer crimes e cominar penas.

Nesse diapasão, o texto constitucional indica matérias sobre as quais o Poder Legislativo deve legislar, de forma obrigatória, não lhe sendo conferida a discricionariedade para optar entre proteger ou não certos bens jurídicos. Trata-se de exigência de aplicação do princípio da legalidade pelo legislador em face de determinadas condutas, consideradas lesivas aos bens jurídicos mais caros à sociedade.

Os mandados de penalização são os seguintes: a) racismo (art. 5 XLII da CF); b)

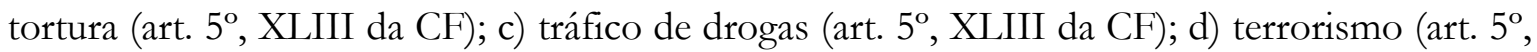
XLIII da CF); e) crimes hediondos (art. $5^{\circ}$, XLIII da CF); f) ação de grupos armados contra a ordem constitucional (art. 5\% XLIV da CF); g) retenção dolosa do salário dos trabalhadores (art. 7, X da CF); h) abuso, violência e exploração sexual da criança ou adolescente (art. 227, $\left.\$ 4^{\circ} \mathrm{da} C F\right)$; i) condutas lesivas ao meio ambiente (art. $225 \mathrm{da} \mathrm{CF}$ ).

\section{Questões polêmicas envolvendo a legalidade penal}

\subsection{Legalidade e reserva legal}

A despeito do sustentado pela doutrina minoritária, o princípio da legalidade não é sinônimo do princípio da reserva legal. O primeiro postulado traduz a submissão à lei, em atuação dentro da esfera estabelecida pelo legislador. Já o outro preceito consiste em estatuir que a regulamentação de determinadas matérias deve ser feita necessariamente por lei. ${ }^{39}$

Nessa ordem de ideias, quando a Constituição outorga poder amplo e geral sobre qualquer espécie de relações, tem-se o princípio da legalidade. De outro lado, quando a Carta

38 _. Direito Penal na Constituição. 3. ed. São Paulo: Revista dos Tribunais, 1995, p. 49.

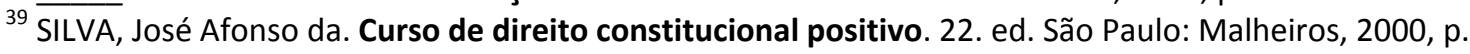
421. 
Maior reserva conteúdo específico à lei, caso a caso, está-se diante do princípio da reserva legal. ${ }^{40}$

Assim, o princípio da legalidade estabelece que ninguém é obrigado a fazer ou deixar de fazer alguma coisa senão em virtude de lei. Já o princípio da reserva legal incide quando uma norma constitucional atribui determinada matéria exclusivamente à lei formal, subtraindo-a à disciplina de outras fontes.

A reserva legal pode ser de duas espécies: a) absoluta, que se verifica quando a disciplina de determinada matéria é reservada constitucionalmente a uma lei, excluindo-se toda fonte infralegal; b) relativa, que ocorre quando a disciplina de determinada matéria é, em parte, admissível a outra fonte diversa da lei (como, por exemplo, um decreto). ${ }^{41}$

\subsection{Abrangência de contravenções penais e medidas de segurança}

Debate-se em âmbito doutrinário e jurisprudencial se a garantia da legalidade incide tão somente quanto a crimes e penas, ou se é aplicável também a contravenções penais e medidas de segurança.

A posição majoritária entende pela interpretação ampla dos termos crime e pena, utilizados pelas normas da Constituição e do Código Penal. Apesar da norma positivada utilizar o termo crime e pena, não há dúvidas que o princípio abarca também a contravenção penal (crime, nesse contexto, tem o sentido de infração penal), e abrange também a medida de segurança (pena, nessa conjuntura, tem o significado de sanção penal). ${ }^{42}$

\subsection{Combinação de leis penais (lex tertia)}

A lex tertia nada mais é do que a combinação de leis penais, por intermédio da aplicação de suas partes benéficas em prol do réu. A lógica desse mecanismo é que se aplica simultaneamente o preceito do tempus regit actum para fazer incidir o preceito benéfico da primeira lei penal, e a cláusula da retroatividade benéfica para que atue o dispositivo favorável da segunda norma penal.

40

Curso de direito constitucional positivo. 22. ed. São Paulo: Malheiros, 2000, p. 421.

41 _ Curso de direito constitucional positivo. 22. ed. São Paulo: Malheiros, 2000, p. 422-423.

42 . Direito Penal. v. 1. São Paulo: Saraiva, 2010, p. 115 
Essa questão, todavia, não é pacífica na doutrina e jurisprudência, gerando celeuma acerca de uma suposta atuação legislativa do magistrado com consequente violação do princípio da legalidade e do princípio da separação dos poderes. Assim, para os críticos da medida, a combinação de leis consistiria em verdadeira criação de uma terceira espécie de norma penal, invadindo campo exclusivo do Poder Legislativo.

Já para os defensores do mecanismo, trata-se de aplicação da teoria dos poderes implícitos (quem pode o mais pode o menos), porquanto se o magistrado pode aplicar toda a lei penal benéfica, igualmente tem a faculdade de aplicar apenas uma parcela dela. O juiz não cria uma nova norma penal, senão movimenta-se dentro dos quadros legais para uma tarefa de integração, que é totalmente legítima. ${ }^{43}$

\subsection{Lei penal em branco}

A norma penal em branco é aquela que necessita de complementação de outro ato normativo, legal ou infralegal, que também passa a ter natureza penal. ${ }^{44}$ Consiste, portanto, em disposição penal cujo preceito é indeterminado quanto ao seu conteúdo, e no qual só se fixa com precisão à parte sancionadora. ${ }^{45}$

A lei penal em branco em sentido lato, homogênea ou imprópria traduz aquela cujo complemento deriva da mesma fonte formal que a editou (Legislativo da União). De outro lado, a lei penal em branco em sentido estrito, heterogênea ou própria possui o complemento decorrente de fonte formal distinta (Executivo - como por exemplo o decreto e a portaria).

Sobre a violação ao princípio da taxatividade por essa espécie de norma penal, não há unanimidade entre os doutrinadores. Existem basicamente duas correntes doutrinárias: a) as normas penais em branco violam o princípio da taxatividade porque, além de não ser exata, não possuindo todos seus elementos incriminadores descritos no tipo penal, o conteúdo da norma penal pode ser modificado sem discussão legislativa madura (vontade do povo) e sem o controle do Executivo; b) as normas penais em branco não ferem o princípio da taxatividade, tendo em conta que apesar de não conter todos os elementos descritivos necessários, define claramente a conduta delitiva, e enquanto a norma não for complementada ela não tem exequibilidade.

43

Curso de Direito Penal. v. 1. São Paulo: Saraiva, 1954, p. 192.

44 _ Comentários ao Código Penal. 3. ed. São Paulo: Revista dos Tribunais, 2006. p. 45.

45 _ Tratado de Direito Penal. v. 1. Campinas: Bookseller, 1997, p. 188. 
A complementação da lei em branco deve ser realizada com cautela, de maneira a respeitar a natureza da norma penal, caso contrário essa manobra consistira na verdade em forma de mascarar uma delegação de competências legislativas penais ${ }^{46}$.

\subsection{Definição de conceitos penais através de tratados internacionais}

Outra interessante questão reside na possibilidade de definição de conceitos penais por meio de tratados internacionais. A principal polêmica, nesse aspecto, consiste na conceituação legal de crime organizado, para fins de aplicação da Lei 9.034/95. Isso porque a Lei do Crime Organizado não define, de forma peremptória, no que consiste a organização criminosa.

Nessa esteira, a doutrina e a jurisprudência majoritárias ${ }^{47}$ entendem que o conceito pode ser extraído da Convenção de Palermo (que dispõe sobre a criminalidade transnacional), referendada pelo Congresso Nacional pelo Decreto Legislativo 231/03, e ratificada pelo Chefe do Executivo através do Decreto 5.015/ 04. O referido Tratado Internacional define organização criminosa como:

grupo estruturado de três ou mais pessoas, existente há algum tempo e atuando concertadamente com o propósito de cometer uma ou mais infrações graves ou enunciadas na Convenção, com a intenção de obter, direta ou indiretamente, um benefício econômico ou outro benefício material.

Há quem não admita que o conceito de organização criminosa seja colhido de tratados internacionas, sob o argumento de que quem celebra tratados é Chefe do Executivo (art. 84, VIII da CF), afrontando a exigência de discussão legislativa da matéria (decorrência do princípio da legalidade da lex populi). Isso pois, mesmo sabendo que o Legislativo se manifesta sobre o tratado por meio de decreto legislativo (art. 49, I da CF), não pode alterar o conteúdo daquilo que foi subscrito pelo Presidente da República, consistindo em mero requisito formal de incorporação do diploma internacional.

Contudo, não merece prosperar essa visão, porquanto a Lei do Crime Organizado não impõe penas para os integrantes de organização criminosa, mas tão somente medidas processuais penais. Para ser apenado por conta da prática da associação para o crime, os

\footnotetext{
${ }^{46}$ PIERANGELI, José Henrique; ZAFFARONI, Eugênio Raúl. Manual de Direito Penal brasileiro: parte geral. 2. ed. São Paulo: Revista dos Tribunais, 1999, p. 450.

${ }^{47}$ STJ, HC 77.771, Rel. Min. Laurita Vaz, DJ 30/05/08.
} 
delinquentes devem satisfazer os requisitos típicos de algum crime tipificado na legislação brasileira, como (a) o art. 288 do CP, (b) o art. 16 e 24 da Lei 7.170/83, (c) o art. $2^{\circ}$ da Lei 2.889/56 ou (d) o art.35 da Lei 11.313/06.

De mais a mais, a utilização da Convenção de Palermo é recomendável até mesmo para a garantia de direitos individuais e da segurança jurídica, pois para a aplicação de medidas processuais penais não basta o mero enquadramento no artigo 288 do Código Penal, exigindose requisitos adicionais (tais como a demonstração da estruturação do grupo e da finalidade de cometer infrações graves), cuja prova é bem mais complexa e trabalhosa.

\section{Escólios finais}

Nessa linha de ideias, fácil constatar que a legalidade não deve ser tomada como regra, senão como princípio, ao se ter em conta que encerra a noção de mandado de otimização, que possui pressuposto fático heterogêneo, tendo a dimensão da importância.

Incide não apenas quanto a crimes e penas, mas também no que se refere a contravenções penais e medidas de segurança.

Dos argumentos desenvolvidos, não é difícil concluir que o princípio possui função nitidamente garantidora (de garantia da lei penal) ${ }^{48}$, ou seja, papel de regulamentação da amplitude e intensidade do exercício do direito de punir do Estado. ${ }^{49}$

Fácil chegar à conclusão que consiste em verdadeira cláusula de liberdade, à medida que sua missão fundamental é proteger o status libertatis dos cidadãos em face de um poder punitivo estatal desarrazoado. ${ }^{50}$ Assegura a preponderância do direito positivo como mecanismo regulador dos conflitos sociais. ${ }^{51}$

O postulado da legalidade traz consigo mais que a mera concepção de não haver crime sem lei anterior que o defina ou pena sem prévia cominação legal, razão pela qual se desdobra em (a) lex praevia, (b) lex scripta, (c) lex certa e (d) lex stricta.

Diante de tudo quanto foi exposto, forçoso reconhecer que o princípio da legalidade reveste-se de caráter basilar em qualquer Estado que se pretenda Democrático de Direito, traduzindo ponto nevrálgico dos ordenamentos jurídicos que se fundem na justiça e na racionalidade. 
Referências Bibliográficas

ALEXY, Robert. Constitucionalismo discursivo. Porto Alegre: Livraria do Advogado, 2008.

BARCELLOS, Ana Paula de. A eficácia jurídica dos princípios constitucionais: o princípio da dignidade da pessoa humana. 2. ed. Rio de Janeiro: Renovar, 2008.

BATISTA, Nilo. Introdução crítica ao direito penal brasileiro. Rio de Janeiro: Revan, 2001.

BRANCO, Paulo Gustavo Gonet; COELHO, Inocêncio Mártires; MENDES, Gilmar Ferreira. Curso de direito constitucional. 2. ed. São Paulo: Saraiva, 2008.

GARCIA, Basileu. Instituições de direito penal. v. 1. t. 1. 5. ed. São Paulo: Max Limonad, 1980.

CAPEZ, Fernando. Curso de Direito Penal: parte geral. 8. ed. São Paulo: Saraiva, 2005.

CERNICCHIARO, Luiz Vicente; COSTA JÚNIOR, Paulo José. Direito Penal na

Constituição. 3. ed. São Paulo: Revista dos Tribunais, 1995.

DWORKIN, Ronald. Levando os direitos a sério. 2. ed. São Paulo: Martins Fontes, 2007.

ESTEFAM, André. Direito Penal. v. 1. São Paulo: Saraiva, 2010.

FEUERBACH, Paul Johann Anselm Ritter Von. Tratado de Derecho Penal. Buenos Aires: Hamurabi, 1989.

FRAGOSO, Heleno Cláudio. Lições de Direito Penal: parte geral. Rio de Janeiro: Forense, 1993.

GRECO, Rogério. Curso de Direito Penal: parte geral. 5. ed. Niterói: Impetus, 2005.

HASSEMER, Winfried. Fundamentos del Derecho Penal. Barcelona: Bosch, 1984.

HASSEMER, Winfried. Introdução dos fundamentos do Direito Penal. Porto Alegre: Sérgio Antônio Fabris, 2005.

LUISI, Luiz. Princípios constitucionais penais. 2. ed. Porto Alegre: Sergio Antônio Fabris Editor, 2003.

MARQUES, José Frederico. Curso de Direito Penal. v. 1. São Paulo: Saraiva, 1954.

MARQUES, José Frederico. Tratado de Direito Penal. v. 1. Campinas: Bookseller, 1997.

MORAES, Alexandre de. Direitos Humanos fundamentais: teoria geral. 4. ed. São Paulo: Atlas, 2002.

NUCCI, Guilherme de Souza. Código Penal comentado. 10. ed. São Paulo: Revista dos Tribunais, 2010. 
PIERANGELI, José Henrique; ZAFFARONI, Eugênio Raúl. Manual de Direito Penal brasileiro: parte geral. 2. ed. São Paulo: Revista dos Tribunais, 1999.

PRADO, Luiz Regis. Comentários ao Código Penal. 3. ed. São Paulo: Revista dos Tribunais, 2006.

PRADO, Luiz Regis. Curso de Direito Penal brasileiro: parte geral. 5. ed. São Paulo: Revista dos Tribunais, 2005.

RÁO, Vicente. O direito e a vida dos direitos. v. 1. São Paulo: Revista dos Tribunais, 1991. ROCHA, Fernando A. N. Galvão da. Direito Penal: parte geral. Niterói: Impetus, 2004.

SILVA, José Afonso da. Curso de direito constitucional positivo. 22. ed. São Paulo: Malheiros, 2000.

TOLEDO, Francisco de Assis. Princípios básicos do Direito Penal. 5. ed. São Paulo: Saraiva, 2002. 